\title{
Determination of Trace Amounts of Bismuth in Water by Hydride Generation Atomic Absorption Spectrometry after Preconcentration with Thionalide-Loaded Silica Gel
}

\author{
Akihiko Haruta, Ken Matsumoto and Kikuo Terada \\ Department of Chemistry, Faculty of Science, Kanazawa University, Kanazawa 920, Japan
}

\begin{abstract}
2-Mercapto-N-2-naphthylacetamide (thionalide)-loaded silica gel is used for preconcentration of bismuth(III) in lower concentration than $\mathrm{gg}^{-1}$ from water samples. Bismuth(III) is quantitatively retained on the loaded gel from $0.1-1.0 \mathrm{M}\left(\mathrm{moll}^{-1}\right)$ nitric acid or $0.1 \mathrm{M}$ hydrochloric acid solutions in batch experiments. Equilibration is achieved within $2 \mathrm{~min}$. The retention capacity of the gel is $2 \mu \mathrm{mol} \mathrm{Bi}(I I I) \mathrm{g}^{-1}$ at $0.25 \mathrm{M}$ nitric acid. The maximum flow velocity for quantitative retention is $2.8 \mathrm{~cm} \mathrm{~min}^{-1}$. Bismuth retained on the column is completely eluted with $10 \mathrm{ml}$ of $4.0 \mathrm{M}$ hydrochloric acid at flow velocity $1.3 \mathrm{~cm} \mathrm{~min}^{-1}$. Bismuth in the effluent is determined by atomic absorption spectrometry with hydride generation; the detection limit is $1.0 \mathrm{ng}$ of bismuth.
\end{abstract}

Keywords Thionalide-loaded silica gel, preconcentration, bismuth(III), water analysis, atomic absorption spectrometry, hydride generation, river water

Bismuth has been industrially utilized as a constituent of many kinds of alloys, semiconductors and contact materials. This element is considered to behave like tin and antimony in hydrosphere. It is thus important to investigate the chemical behavior of this element in natural waters from the standpoint of environmental pollution control. However, the concentrations of bismuth in seawater and rainwater have been reported by $\mathrm{Lee}^{1}$ to be as low as $0.13-2.0 \mathrm{ng} \mathrm{kg}^{-1}$ and $3.2 \mathrm{ng} \mathrm{kg}^{-1}$, respectively. On the other hand, the detection limit of the most sensitive method for bismuth analysis, e.g., atomic absorption spectrometry ${ }^{2}$ and atomic fluorescence spectrometry ${ }^{3,4}$ with hydride generation have been reported to be $0.2 \mathrm{ng} \mathrm{m}^{-1}$ and $0.005 \mathrm{ng}$ $\mathrm{ml}^{-1}$, respectively. Therefore, preconcentration is essential for its precise determination from natural water samples.

The present authors have previously reported a preconcentration method of bismuth(III) with 2,5dimercapto-1,3,4-thiadiazole (Bismuthiol I) loaded silica gel. But the sorption of the element on the gel was considerably influenced by the chloride ion concentration, so that it was difficult to apply the method to seawater samples. 5

The thionalide-loaded silica gel, however, revealed efficient sorption of antimony(III) from seawater ${ }^{6}$, and was found to also sorb bismuth(III) even at lower $\mathrm{pH}$ values. In the present paper, the method for preconcentration and determination of bismuth(III) by the use of thionalide-loaded silica gel followed by atomic absorption measurement with hydride generation is described.

\section{Experimental}

\section{Reagents}

A standard bismuth(III) solution (1000 $\left.\mathrm{mg} \mathrm{l}^{-1}\right)$ was prepared by dissolving $1.000 \mathrm{~g}$ of bismuth metal $(99.99 \%$ purity) in $10 \mathrm{ml}$ of $(1+1)$ nitric acid and diluting with $(1+10)$ nitric acid to $1000 \mathrm{ml}$. 2-Mercapto- $N$-2-naphthylacetamide (thionalide, Tokyo Kasei) and tetrahydrofuran (THF) were of analytical reagent grade. THF was purified by distillation. Acids of analytical reagent grade were used without further purification. Sodium tetrahydroborate $\left(\mathrm{NaBH}_{4}\right)$ was reagent for organic synthesis and a $1 \%$ aqueous solution $(0.3 \%$ sodium hydroxide) was freshly prepared each time.

Silica gel (chromatographic grade, Wakogel C-100) was sieved through a nylon sieve (60-80 mesh), soaked with twice its volume of $(1+1)$ hydrochloric acid for $1 \mathrm{~d}$ at $90^{\circ} \mathrm{C}$, and washed with deionized water until free from chloride. The gel was soaked with twice its volume of $(1+2)$ nitric acid for $1 \mathrm{~d}$ at $90^{\circ} \mathrm{C}$, washed with deionized water, dried at $110^{\circ} \mathrm{C}$ for $1 \mathrm{~d}$ and stored in a polyethylene bottle kept in a desiccator over silica gel. Deionized water was prepared with a Barnstead "NANOpure" system and was used throughout. 
Preparation of thionalide-loaded silica gel (thionalide-SG)

About $100 \mathrm{ml}$ of THF containing $6 \mathrm{~g}$ of thionalide was slowly added from a separatory funnel into $50 \mathrm{~g}$ of a degassed silica gel, which was previously activated at $110^{\circ} \mathrm{C}$ for $20 \mathrm{~h}$, and then placed in a suction bottle. After standing for $10 \mathrm{~h}$ in a refrigerator at $4^{\circ} \mathrm{C}$, the impregnated gel was heated at $40^{\circ} \mathrm{C}$ under reduced pressure for $4 \mathrm{~h}$ to expel the solvent completely. The reagent-loaded gel was added into a certain volume of deionized water and the floated reagent was removed by decantation. Finally, the gel was dried under reduced pressure for $24 \mathrm{~h}$ at $40^{\circ} \mathrm{C}$, and stored in a polyethylene bottle kept in a desiccator.

\section{Apparatus}

A Shimadzu AA-646 atomic absorption spectrophotometer was used for the determination of bismuth in the concentration above $1 \mu \mathrm{g} \mathrm{ml}^{-1}$, while for concentrations of the element lower than $1 \mu \mathrm{g} \mathrm{ml}^{-1}$, a Hitachi 170-50 atomic absorption spectrometer was used in conjunction with a Nippon Jarrell-Ash Model XYD-1 continuous hydride generator which was connected with a quartz cell (10 $\mathrm{mm}$ i.d., $180 \mathrm{~mm}$ long) by Teflon tubing. The cell was heated to about $1000^{\circ} \mathrm{C}$ with Kanthal alloy wire which surrounded the cell. A Hitachi-Horiba $\mathbf{p H}$ meter, $\mathrm{M}-5$, was used to check the $\mathrm{pH}$ of the aqueous solution. An Iwaki VS electric shaker, and a Toyo SF160K fraction collector and Tokyo Rikakikai MP-3 micro pump were used for the batch and column experiments, respectively. A Shimadzu UV-120-02 spectrophotometer was used for determination of thionalide. The column experiments were carried out in a Yamato Kagaku PGV-750 APG-type clean bench (class 100).

\section{Batch experiments}

A $20 \mathrm{ml}$ of bismuth(III) solution ( $\left.0.5 \mathrm{mg} \mathrm{l}^{-1}\right)$, adjusted to desired acidity or $\mathrm{pH}$ value, and $0.5 \mathrm{~g}$ of thionalideSG were put into a 50-ml glass stoppered centrifuge tube. The contents were shaken at 200 strokes min $^{-1}$ for $30 \mathrm{~min}$ at room temperature. After filtration of the solution through a dry sheet of Toyo No. 5A filter paper, the bismuth concentration of the filtrate was measured by atomic absorption spectrometer and the $\mathrm{pH}$ of the solution was also measured.

\section{Column experiments}

A glass tube $(10 \mathrm{~mm}$ i.d., $140 \mathrm{~mm}$ long) was filled with a water slurry of $1.0 \mathrm{~g}$ of the thionalide-SG and washed with deionized water. A small disc of Toyo No. 5C filter paper was placed on top so that the gel was not disturbed during sample passage. A given volume of sample solution containing bismuth(III) ion was percolated through the column at various flow velocities which were adjusted by the MP-3 pump. After passage of the sample solution, $10 \mathrm{ml}$ of $4 \mathrm{M}$ hydrochloric acid was passed through the column and the effluent was collected by a fraction collector or a measuring flask. The concentration of bismuth was then measured as described above.

\section{Results and Discussion}

\section{Characteristics of thionalide-SG}

The amount of thionalide loaded on silica gel was measured as described previously6,7 and was found to be $53.8 \mathrm{mg} \mathrm{g}^{-1}\left(0.248 \mathrm{mmol} \mathrm{g}^{-1}\right)$ as the average of three determinations. The sorption capacity for bismuth was measured by the breakthrough method by use of $5 \mu \mathrm{g} \mathrm{ml}^{-1} \mathrm{Bi}(\mathrm{III})$ solution and $1.0 \mathrm{~g}$ of the loaded gel. In $0.25 \mathrm{M}$ nitric acid solution, the capacity of the gel was found to be $0.44 \mathrm{mg} \mathrm{Bi}$ (III) $\mathrm{g}^{-1}\left(2.1 \mu \mathrm{mol} \mathrm{g}^{-1}\right)$ as the average of three runs. Though the sorption capacity of the gel is smaller than those of organic polymer exchange resins, this has little effect on the preconcentration of micro amounts of bismuth.

\section{Effect of acid concentration and shaking time on retention of bismuth}

The retention of bismuth(III) ion from aqueous solutions at various acidities was examined by the batch method, using $0.5 \mu \mathrm{g} \mathrm{ml}^{-1} \mathrm{Bi}$ (III) solution. In Fig. 1, the results obtained from nitric acid solution are compared with those obtained from hydrochloric acid medium. In the case of nitric acid medium, bismuth was quantitatively retained on the gel at acidity lower than $1.0 \mathrm{M}$. In hydrochloric acid medium, retention suddenly began at acidity $2 M$, and then reached complete retention at $\mathrm{pH}$ 1.0. The quantitative retention occurs at $\mathrm{pH}$ higher than 2; a part of bismuth may be sorbed as its oxychloride precipitate, because bismuth(III) gives the precipitate at $\mathbf{p H}$ above 1.0. The reduction in sorption with higher hydrochloric acid concentration is explained by formation of bismuth chloride and hydroxychloride complexes, in which the chloride ion should compete with thionalide in complexing to bismuth. The retention of bismuth from $0.25 \mathrm{M}$ nitric acid solution of $5 \mu \mathrm{g} \mathrm{ml}^{-1} \mathrm{Bi}$ (III) was

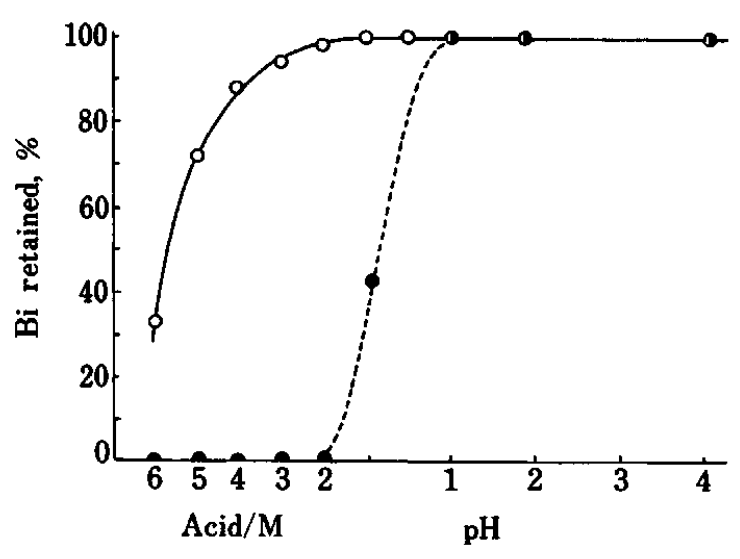

Fig. I Effect of acid concentration on retention of Bi(III): (O) nitric acid; (O) hydrochloric acid. $\mathrm{Bi}\left(0.5 \mu \mathrm{g} \mathrm{ml}^{-1}\right) 20 \mathrm{ml}$; Thionalide-SG, $0.5 \mathrm{~g}$. 


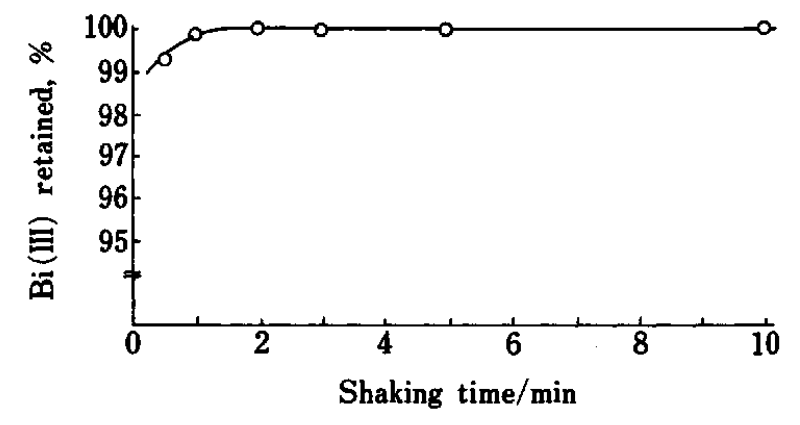

Fig. 2 Effect of shaking time on retention of Bi(III).

Table 1 Recovery of bismuth on thionalide-SG column

\begin{tabular}{lcccc}
\hline $\begin{array}{c}\mathrm{Bi}(\mathrm{III}) / \\
\mu \mathrm{g} \mathrm{I}^{-1}\end{array}$ & $\begin{array}{c}\text { Sample } \\
\text { vol./ml }\end{array}$ & $\begin{array}{c}\text { Thionalide-SG } \\
\text { used } / \mathrm{g}\end{array}$ & $\begin{array}{c}\text { Flow vel./ } \\
\mathrm{cm} \mathrm{min}^{-1}\end{array}$ & $\begin{array}{c}\text { Recovery } \\
\%\end{array}$ \\
\hline 5.0 & 25 & 1.0 & 1.3 & 102.0 \\
& & 1.0 & 2.8 & 101.9 \\
& & 1.0 & 4.3 & 74.3 \\
$5.0^{\mathrm{b}}$ & 100 & 1.0 & 2.8 & 100.3 \\
0.01 & 1000 & 1.0 & 2.8 & 99.8 \\
$0.01^{\mathrm{c}}$ & 1000 & 1.0 & 2.8 & 99.3 \\
$0.01^{\mathrm{b}}$ & 1000 & 1.0 & 2.8 & 27.5 \\
\hline
\end{tabular}

Eluent: 4.0 M HCl.

a. Figures are the average of three determinations.

b. Seawater spiked with $\mathrm{Bi}$ (III).

c. River water spiked with $\mathrm{Bi}(\mathrm{III})$.

examined after various shaking times. The results showed that above $99.0 \%$ of bismuth was sorbed within $30 \mathrm{~s}$, that the quantitative retention was achieved within $2 \mathrm{~min}$, and that the retention was constant for at least 10-min shaking (Fig. 2).

\section{Retention of bismuth on the column}

The retention of bismuth from $25 \mathrm{ml}$ of $0.25 \mathrm{M}$ nitric acid solution $\left(5 \mu \mathrm{g} \mathrm{Bi}(\mathrm{III}) \mathrm{ml}^{-1}\right)$ was examined at various flow velocities by use of $1.0 \mathrm{~g}$ of thionalide-SG. The retained bismuth was eluted with $10 \mathrm{ml}$ of $4 \mathrm{M}$ hydrochloric acid and determined by atomic absorption spectrometry with hydride generation. The results proved that the bismuth was quantitatively retained from $25 \mathrm{ml}$ of the solution at flow velocities lower than $2.8 \mathrm{~cm} \mathrm{~min}$. Furthermore, the complete retention was also achieved by passing $100 \mathrm{ml}$ of seawater sample spiked with $0.5 \mu \mathrm{g}$ of bismuth through the same column at a flow velocity of $2.8 \mathrm{~cm} \mathrm{~min}^{-1}$ (Table 1). However, when the bismuth concentration is much lower $\left(10 \mathrm{ng}^{-1}\right)$ and the sample volume is larger $(1000 \mathrm{ml})$, the recovery of the element decreased to only $28 \%$. On the other hand, such a lower recovery was never observed in the cases where deionized water or fresh water samples were used under the same conditions. It is therefore assumed that in very low concentration of bismuth, chloride ion considerably hinders the complexation of bismuth with thionalide, but the effect is less extensive than that for

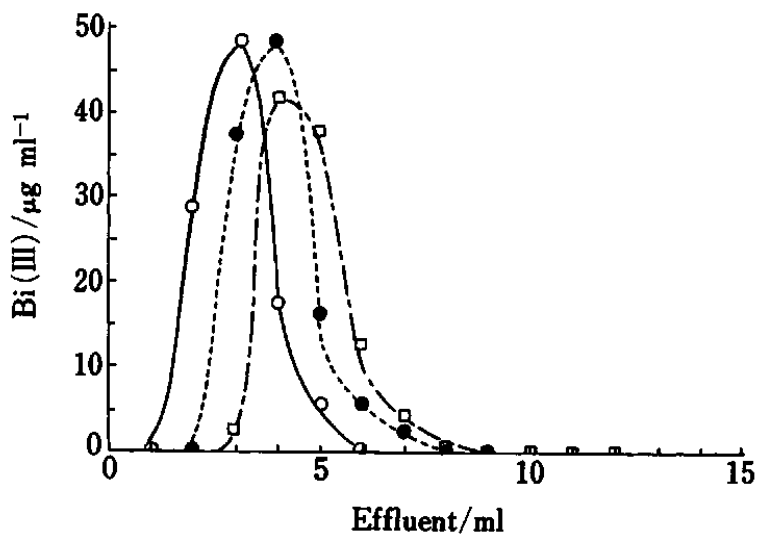

Fig. 3 Elution of bismuth retained on thionalide-SG column by: (O) $6 \mathrm{M} \mathrm{HCl}$; (O) $4 \mathrm{M} \mathrm{HCl}$; (प) $2 \mathrm{M} \mathrm{HCl}$.

the complexation with Bismuthiol I. ${ }^{5}$

The thionalide-SG may satisfactorily be used for the preconcentration of bismuth from the water samples of low chloride concentration, e.g., rain, river and lake waters, but not seawater. Table 1 also shows that preconcentration of bismuth at the sub-ppb level from 101 of water sample can be achieved within $20 \mathrm{~h}$ using a wider column ( $20 \mathrm{~mm}$ i.d.) filled with $4.0 \mathrm{~g}$ of the gel.

\section{Elution of bismuth}

As can be seen from Fig. 1, bismuth retained on the loaded gel is expected to be eluted with hydrochloric acid of higher acidity than $2.0 \mathrm{M}$. Thus, 2,4 and $6 \mathrm{M}$ hydrochloric acids were passed through the column retained $100 \mu \mathrm{g}$ of bismuth at a flow velocity of $1.3 \mathrm{~cm} \mathrm{~min}^{-1}$. The effluent was collected by a fraction collector, and bismuth in each fraction was determined by atomic absorption spectrometry with hydride generation. From the results shown in Fig. 3, it is evident that $10 \mathrm{ml}$ of $4.0 \mathrm{M}$ hydrochloric acid can completely release bismuth from the column. This effluent can be directly submitted to the following atomic absorption measurement, as will be described later.

\section{Effect of various substances on the retention of bismuth}

Several metal ions which might react with thionalide in $0.25 \mathrm{M}$ nitric acid medium, such as antimony(III), copper(II), gold(III), mercury(II), palladium(II), platinum (IV), silver(I) and tin(IV) were investigated for their effect on the preconcentration process. A $100 \mathrm{ml}$ of water sample of $5 \mu \mathrm{g} \mathrm{l}^{-1} \mathrm{Bi}$ (III) along with one of the other ions in the concentration of $10 \mu \mathrm{g} \mathrm{l}^{-1}$ was passed through the column of $1.0 \mathrm{~g}$ of the gel. The results are shown in Table 2. At the concentration tested, antimony, gold and platinum somewhat reduced the retention of bismuth, but in the concentration of $5 \mu \mathrm{g}$ $\mathrm{l}^{-1}$, they gave little effect. Since there are few natural waters containing these ions in such high concentrations as listed in the table, their influence will be negligible in practice.

The effect of some organic ligands was also examin- 
Table 2 Effect of diverse ions and ligands on the recovery of bismuth(III)

\begin{tabular}{lcc}
\hline lon or ligand & $\begin{array}{c}\text { Concentration/ } \\
\mu \mathrm{g} \mathrm{I}^{-1}\end{array}$ & $\begin{array}{c}\text { Recovery of } \mathrm{Bi}(\mathrm{III})^{\mathrm{a}} \\
\%\end{array}$ \\
\hline $\mathrm{Ag}(\mathrm{I})$ & 10 & 99.0 \\
$\mathrm{Au}(\mathrm{III})$ & 10 & 94.2 \\
$\mathrm{Cu}(\mathrm{II})$ & 10 & 98.2 \\
$\mathrm{Hg}(\mathrm{II})$ & 10 & 100 \\
$\mathrm{Pd}(\mathrm{II})$ & 10 & 97.5 \\
$\mathrm{Pt}(\mathrm{IV})$ & 10 & 92.0 \\
$\mathrm{Sb}(\mathrm{III})$ & 10 & 86.4 \\
& 5 & 101.0 \\
$\mathrm{Sn}(\mathrm{IV})$ & 10 & 98.2 \\
$\mathrm{EDTA}$ & $10^{-10} \mathrm{M}$ & 94.0 \\
& $10^{-11} \mathrm{M}$ & 100.0 \\
Citrate & $10^{-3} \mathrm{M}$ & 99.2 \\
Tartrate & $10^{-7} \mathrm{M}$ & 93.0 \\
& $10^{-8} \mathrm{M}$ & 101.2 \\
\hline
\end{tabular}

Bi(III) added: $5 \mu \mathrm{g} \mathrm{l}^{-1}$. Sample volume: $100 \mathrm{ml}$.

a. Figures are the average of three determinations.

ed. The results are shown in Table 2. Even in very low concentration, EDTA and tartrate considerably hindered retention of bismuth. These results may be attributed to the high stability of their complexes of the element. However, in natural waters, these substances, particularly EDTA, rarely exist in the level listed and therefore, influence of these substances will be negligibly small.

\section{Atomic absorption spectrometry with hydride generation for bismuth}

The effluent containing bismuth eluted from the gel column (4.0 M hydrochloric acid) was made up to $20 \mathrm{ml}$ with deionized water. This solution and alkaline sodium tetrahydroborate solution were continuously introduced into the hydride generator. The experimental conditions chosen in the present study are summarized in Table 3. The generated bismuth trihydride was trapped in a U-tube containing fine glass beads and dipped in a liquid nitrogen bath. After the carrier gas was passed through for $3 \mathrm{~min}$, the tube was transferred in a mantle heater to expel the hydride into an AAS cell. Under the conditions, the detection limit was $1.0 \mathrm{ng}$ and the calibration curve was straight in the concentration range of $0.1-2.0 \mathrm{ng} \mathrm{ml}^{-1}$.

\section{Analysis of water samples for bismuth}

The present method was applied to river water samples. The samples were collected from the Sai river and the Tatsumi canal, which originates from the Sai river, and the Asano river, Kanazawa City. The samples were brought to the laboratory and filtered through a millipore filter $(0.45 \mu \mathrm{m}$ pore $)$ and acidified by adding $18 \mathrm{ml}$ of nitric acid to each 11 of the sample. The analytical data are summarized in Table 4 . The bismuth concentration of the Tatsumi canal was fairly
Table 3 Optical operating conditions for hydride generation AAS of bismuth

\begin{tabular}{lc}
\hline AAS & \\
Wavelength & $223.5 \mathrm{~nm}$ \\
Lamp current & $10 \mathrm{~mA}$ \\
Slit width & $1.1 \mathrm{~mm}$ \\
Gain & 2.0 \\
Hydride generation & \\
Sample solution acidity & $4.0 \mathrm{M} \mathrm{HCl}$ \\
Sample solution flow rate & $20.0 \mathrm{ml} \mathrm{min}$ \\
$\mathrm{NaBH}_{4}$ solution concentration & $1.0 \%(\mathrm{w} / \mathrm{v}) \mathrm{in}$ \\
& $0.5 \%(\mathrm{w} / \mathrm{v}) \mathrm{NaOH}$ \\
& $12.0 \mathrm{ml} \mathrm{min}^{-1}$ \\
NaBH & $2.0 \mathrm{M} \mathrm{HCl} \mathrm{HCl}$ \\
Acid solution flow rate & $12.0 \mathrm{ml} \mathrm{min}^{-1}$ \\
Acid solution flow rate & $0.11 \mathrm{~min}^{-1}$ \\
Carrier gas (I) flow rate & $0.51 \mathrm{~min}^{-1}$ \\
Carrier gas (II) flow rate &
\end{tabular}

Table 4 Determination of $\mathrm{Bi}$ in samples of river water

\begin{tabular}{lcc}
\hline \multicolumn{1}{c}{ Location } & $\begin{array}{c}\text { Sample } \\
\text { volume } / \mathrm{ml}\end{array}$ & $\begin{array}{c}\text { Bi contents/ } \\
\mathrm{ng} \mathrm{l}^{-1}\end{array}$ \\
\hline Sai river ${ }^{\mathrm{a}}$ (Kanazawa) & 1000 & 2.4 \\
Tatsumi canal $^{\mathrm{b}}$ (Kanazawa) & 1500 & 3.4 \\
Asano river ${ }^{\mathrm{b}}$ (Kanazawa) & 1500 & n.d. \\
\hline
\end{tabular}

a. $4.0 \mathrm{~g}$ of thionalide-SG was used (column: $20 \mathrm{~mm}$ i.d.).

b. $1.0 \mathrm{~g}$ of thionalide-SG was used (column: $10 \mathrm{~mm}$ i.d.).

consistent with that for the Sai river, while no bismuth could be detected in the sample from the Asano river. Because the determination limit under the present conditions is $0.1 \mathrm{ng} \mathrm{ml}^{-1}$, the bismuth content in the sample from the Asano river may be estimated as lower than $1.0 \mathrm{ng} \mathrm{l}^{-1}$.

The authors acknowledge their thanks to the Ministry of Education, Science and Culture for financial support (Grantin-Aid for General Scientific Research No. 63470028).

\section{References}

1. D. S. Lee, Anal. Chem., 54, 1682 (1982).

2. K. C. Thompson and D. R. Thomerson, Analyst [London], 99, 595 (1974).

3. K. Tsujii and K. Kuga, Anal. Chim. Acta, 72, 85 (1974).

4. T. Nakahara, K. Nakanishi and T. Wasa, Spectrochim. Acta, 42B, 119 (1987).

5. K. Terada, K. Matsumoto and Y, Nanao, Anal. Sci., 1, 145 (1985).

6. H. Fukuda, J. Tsunoda, K. Matsumoto and K. Terada, Bunseki Kagaku, 36, 683 (1987).

7. M. Matsui, K. Matsumoto and K. Terada, Anal. Chim. Acta, 193, 381 (1987).

(Received January 7, 1989) (Accepted February 8, 1989) 